\title{
SISTEM PENDUKUNG KEPUTUSAN PEMILIHAN MOBIL BEKAS DENGAN METODE AHP DAN SAW PADA NAVA SUKSES MOTOR
}

\author{
Irawan Setiadi \\ Program Studi Informatika, Universitas Indraprasta PGRI \\ irawan.setiadi91@gmail.com
}

\begin{abstract}
Abstrak
Seseorang pembeli kendaraan bekas dalam menentukan pilihannya, tentu didasarkan pada beberapa kriteria yang dijadikan patokan dalam memilih kendaraan mobil bekas antara lain mesin, body, interior, nomor rangka \& mesin, surat-surat \& pajak, dan harga. Kriteria tersebut menjadi pertimbangan untuk membeli mobil bekas, berbagai pertimbangan dilakukan oleh seorang pembeli agar mendapatkan mobil bekas yang baik dan bagus. Kesulitan dalam memilih mobil bekas maka perlu suatu rujukan sebagai dasar pemikiran dalam memilih mobil bekas. Sistem pendukung keputusan menawarkan solusi untuk rujukan dalam memilih mobil bekas. Sistem pendukung keputusan yang ditawarkan menggunakan Analytical Hierarchy Process (AHP) dan Simple Additive Weighting (SAW) dalam menyelesaikan persoalan. Persoalan bisa diselesaikan dengan menggunakan sistem perangkingan berdasarkan bobot global. Pembeli kendaraan mobil bekas dapat memilih mobil bekas berdasarkan rujukan atau rekomendasi dari sistem pendukung keputusan yang dijalankan oleh pakar. Berdasarkan hasil perhitungan faktor kriteria-kriteria penilaian yang diajukan ke sistem maka penentuan mobil bekas diperoleh melalui perhitungan nilai bobot prioritas untuk pemilihan alternatif mobil bekas yang akan dibeli. Dengan adanya Sistem Pendukung Keputusan untuk memilih mobil bekas dengan menggunakan metode Analytical Hierarchy Process (AHP) dan Simple Additive Weighting (SAW) dalam penentuan mobil bekas tingkat akurasi nya mencapai $73 \%$ dibandingkan dengan menggunakan metode Simple Additive Weighting (SAW) saja yang memiliki tingkat akurasi hanya $60 \%$.
\end{abstract}

Kata Kunci : SPK, Pembeli, Mobil Bekas, AHP, SAW

\begin{abstract}
Abstrack
Someone buying a used vehicle in determining his choice, of course, is based on several criteria that are used as a benchmark in choosing used car vehicles, including engines, body, interior, frame number \& engine, letters \& taxes, and prices. These criteria are a consideration for buying a used car, various considerations are made by a buyer to get a good and good used car. Difficulties in choosing a used car, a reference is needed as a rationale for choosing a used car. Decision support systems offer a solution for referrals in choosing a used car. Decision support systems offered using Analytical Hierarchy Process (AHP) and Simple Additive Weighting (SAW) in solving problems. Problems can be solved using a ranking system based on global weighting. Buyers of used car vehicles can choose used cars based on references or recommendations from expert decision support systems. Based on the results of the calculation of the assessment criteria proposed to the system, the determination of used cars is obtained through calculating the priority weight values for the selection of used cars to be purchased. With the Decision Support System to choose used cars using the Analytical Hierarchy Process (AHP) method and Simple Additive Weighting (SAW) in determining used cars the accuracy rate is $73 \%$ compared to using the Simple Additive Weighting (SAW) method which has a level of accuracy only $60 \%$.
\end{abstract}

Keywords : SPK, Buyer, Second hand Car, AHP, SAW

\section{PENDAHULUAN}

Kendaraan mobil merupakan salah satu alat transportasi yang banyak dibutuhkan oleh masyarakat karena mobil dapat menampung banyak orang dan juga cocok digunakan untuk bepergian jauh karena akan terhindar dari panas sinar matahari 
dan hujan. Mobil merupakan salah satu kebutuhan primer, ini berlaku untuk masyarakat ekonomi kelas atas. Dimana mobil sekarang bukanlah barang langka, dan bagi kaum yang memiliki uang berlebih merupakan sebuah kebutuhan yang harus dipenuhi karena fungsi dari mobil sangatlah bermanfaat.

Bagi sebagian masyarakat seringkali mengalami kendala untuk membeli mobil baru karena keterbatasan ekonomi, sehingga memilih membeli mobil bekas. Mobil bekas merupakan mobil yang pernah dimiliki oleh orang lain. Harga mobil bekas umumnya lebih murah daripada mobil baru dan dijual melalui showroom mobil bekas atau ditawarkan secara langsung oleh pemiliknya. Jenis mobil bekas yang dijual dishowroom antara lain jenis SUV, MPV dan sedan dari berbagai merk dan tahun.

Tujuan dari sistem pendukung keputusan (SPK) ini antara lain untuk mendukung keputusan pada proses pengambilan keputusan menggunkan alternatif-alternatif yang diperoleh dari hasil pengolahan data, informasi dan rancangan model. Karakteristik dari SPK ini adalah mendukung seluruh kegiatan organisasi, mendukung beberapa keputusan yag saling berinteraksi, terdapat dua komponen yaitu data dan model yang bersifat konstan [1].

Sistem pendukung keputusan pemilihan mobil bekas berbasis website ini dibutuhkan oleh showroom Nava Sukses Motor tidak hanya untuk membantu sales namun juga dapat dimanfaatkan oleh calon pembeli. Saat ini dalam membangun sistem pengambilan keputusan sudah ada beberapa metode yang dapat digunakan untuk membantu proses pengambilan keputusan. Beberapa metode sistem pendukung keputusan dalam menentukan mobil bekas bagus dan terbaik antara lain Analytical Hierarchy Process, Simple Additivie Weighting [2], Fuzzy Multiple
Attribute Decission Making Technique For Other Preference by Similarity to Ideal Solution. Metode yang digunakan dalam penelitian ini menggunakan sistem pendukung keputusan dengan menggunakan metode Analytical Hierarchy Process (AHP) dan Simple Additivie Weighting (SAW).

\section{METODE PENELITIAN}

\section{Metode Penelitian}

Metodologi penelitian yang dipakai dalam model sistem pengambilan keputusan pemilihan pembelian mobil bekas menggunakan metode kuantitatif. Penelitian kuantitatif mengembangkan dan menggunakan model-model matematis, teori-teori dan hipotesis. Kriteria-kriteria yang ada sudah ditentukan sejak awal penelitian, dimana satu atau lebih faktor divariasikan dan faktor lain yang dibuat konstan.

\section{a. Metode Pemilihan Sampel}

Dalam pemilihan sampel digunakan metode Sampling Non Random Purposive, dimana kriteria sampel ditetapkan terlebih dahulu, sampel diambil yang memenuhi kriteria saja. Sampel yang dipilih pada penelitian ini adalah masyarakat umum di Jakarta Selatan. Jenis penelitian yang dilakukan adalah jenis penelitian informasi kuantitatif yaitu pengambilan data yang telah dikumpulkan oleh showroom Nava Sukses Motor Tahun 2013-2016. Berikut merupakan data calon pembeli yang berminat dan pembeli mobil bekas:

Tabel 1. Data Calon Pembeli dan Pembeli 2013-2016

\begin{tabular}{|c|c|c|}
\hline Tahun & $\begin{array}{c}\text { Jumlah Calon } \\
\text { Pembeli }\end{array}$ & Pembeli \\
\hline 2013 & 175 & 75 \\
\hline 2014 & 120 & 75 \\
\hline 2015 & 132 & 80 \\
\hline 2016 & 183 & 80 \\
\hline Jumlah & $\mathbf{6 1 0}$ & $\mathbf{3 1 0}$ \\
\hline \multicolumn{2}{|c|}{ (Sumber: Nava Sukses Motor) }
\end{tabular}




\section{b. Metode Pengumpulan Data}

Metode pengumpulan data [3] yang digunakan peneliti dalam merancang sistem pendukung keputusan pemilihan mobil bekas adalah sebagai berikut :

1. Studi Pustaka, yaitu pengumpulan data yang diperoleh dengan mempelajari, meneliti, dan membaca buku, informasi dari internet, jurnal, skripsi, tesis yang berhubungan dengan masalah yang diteliti.

2. Wawancara, yaitu dengan melakukan tanya jawab dan bertatap muka langsung dengan pihak yang berkaitan langsung dengan sistem pendukung keputusan pembelian mobil bekas, dalam hal ini Nava Sukses Motor sebagai obyek penelitian dan sumber informasi penelitian, sehingga pengumpulan data dan informasi akan lebih relevan dan akurat.

3. Kuesioner, yaitu membuat daftar pertanyaan tertulis yang telah disusun sebelumnya, kemudian membagikannya kepada responden. Dalam hal ini responden adalah masyarakat luas dan Nava Sukses Motor. Diharapkan akan didapat feedback yang relevan dan akurat.

a. Data Primer

Adalah data yang diperoleh secara langsung dari sumber, laporan-laporan pembelian kendaraan mobil bekas tahun 2013 - 2016.

b. Data Sekunder

Adalah data yang diperoleh secara tidak langsung, misalnya dari literatur, dokumentasi, buku, jurnal dan informasi lainnya yang berhubungan dengan masalah pendukung keputusan dalam pembelian mobil bekas.

\section{Langkah - Langkah Penelitian}

Langkah-langkah dalam penelitian merupakan rangkaian prosedur yang harus dijalani tahap demi tahap supaya sesuai apa yang menjadi tujuan. Dengan langkah langkah penelitian yang telah tersusun dengan baik maka diharapkan segala aktivitas dan kegiatan penelitian dapat terprogram dengan baik pula. Mudah dalam evaluasi dan melengkapi serta memperbaiki apabila ada hal-hal yang memang harus disempurnakan demi tujuan tersebut. Langkah-langkah penelitian harus dilaksanakan dengan urut dan struktur sesuai dengan SOP masing-masing. Dengan langkah yang urut dan terstruktur ini harus diselesaikan mulai dari awal hingga akhir proses. Selain menjalankan prosedur yang telah dibuat dengan SOP, wawancara, mengumpulkan data-data yang digunakan dalam memecahkan masalah tersebut. Dan setiap langkah-langkah penelitian didokumentasikan.

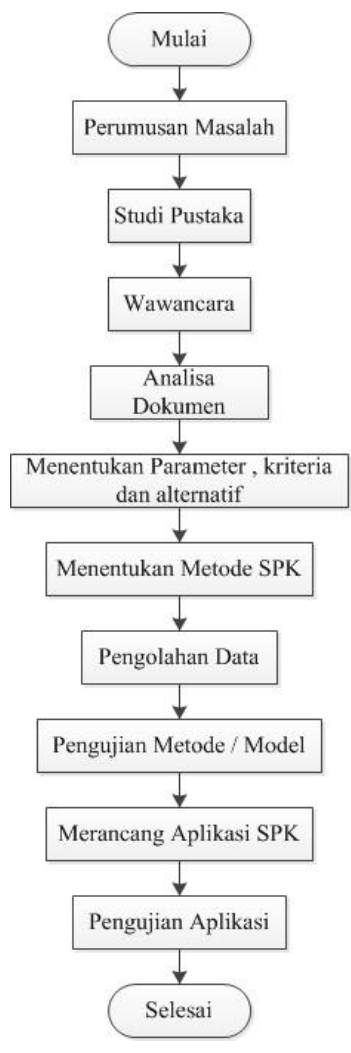

Gambar 1. Langkah - Langkah Penelitian 
3. HASIL DAN PEMBAHASAN Analisis Data

\section{Teknik Analisis Metode AHP}

Terdapat tiga prinsip utama dalam pemecahan masalah dalam AHP (Analytical Hierarchy Process), yaitu: Decomposition, Comparative Judgement dan Logical Concistency. Secara garis besar prosedur AHP (Analytical Hierarchy Process) meliputi tahapan sebagai berikut:

1. Dekomposisi masalah;

2.Penilaian/pembobotan untuk membandingkan elemen-elemen;

3. Penyusunan matriks dan uji consistensi;

4. Penetapan prioritas pada masing-masing hirarki;

5. Sintesis dari prioritas; dan

6. Pengambilan/penetapan keputusan

\section{Teknik Analisis Metode SAW}

Metode SAW (Simple Additive Weighting) sering juga dikenal istilah metode penjumlahan terbobot. Konsep dasar metode SAW (Simple Additive Weighting) adalah mencari penjumlahan terbobot dari rating kinerja pada setiap alternatif pada semua atribut. Metode SAW (Simple Additive Weighting) membutuhkan proses normalisasi matriks keputusan (X) ke suatu skala yang dapat diperbandingkan dengan semua rating alternatif yang ada.

Tahapan Metode SAW (Simple Additive Weighting)

1. Menentukan kriteria-kriteria yang akan dijadikan acuan dalam pengambilan keputusan yaitu $\mathrm{C} 1$.

2. Menentukan rating kecocokan setiap alternatif pada setiap kriteria.

3.Membuat matriks keputusan berdasarkan kriteria (C1), kemudian melakukan normalisasi matriks berdasarkan persamaan yang disesuaikan dengan jenis atribut sehingga diperoleh matriks ternormalisasi R.

4. Hasil akhir diperoleh dari proses perankingan yaitu penjumlahan dari perkalian matriks ternormalisasi $\mathrm{R}$ dengan vector bobot sehingga diperoleh nilai terbesar yang dipilih sebagai alternatif terbaik (A1) sebagai solusi.

\section{Penentuan Kriteria Pemilihan Mobil Bekas}

Pemberian nilai bobot data kriteria mengacu pada penelitian sebelumnya dengan judul Implementasi Metode Simple Additive Weighting (SAW) pada Sistem Pengambilan Keputusan Sertifikasi Guru [4] yang menjelaskan bahwa bobot perhitungan SAW jumlah nilai bobotnya 1 atau 100. Data kriteria dapat dilihat pada tabel berikut:

\section{Tabel 2. Data Kriteria}

\begin{tabular}{|c|c|c|c|}
\hline No. & Kriteria & Atribut & Bobot \\
\hline 1 & Tahun Pembuatan & Benefit & 50 \\
\hline 2 & Kapasitas Mesin & Benefit & 20 \\
\hline 3 & Warna Mobil & Benefit & 20 \\
\hline 4 & Harga Beli & Cost & 10 \\
\hline
\end{tabular}

(Hasil analisis, 2016. Sumber: Nava Sukses Motor)

\section{Data Sub Kriteria Pemilihan Mobil Bekas}

Data sub kriteria merupakan data penunjang yang digunakan dalam perhtungan prioritas kriteria. Data Kriteria memiliki bobot preferensi atau tingkat kepentingan dari setiap kriteria [5] dengan nilai:

$$
\begin{aligned}
& 1=\text { sangat rendah } \\
& 2=\text { rendah } \\
& 3=\text { sedang } \\
& 4=\text { tinggi } \\
& 5=\text { sangat tinggi }
\end{aligned}
$$

Bobot yang digunakan dalam penelitian ini, berdasarkan hasil wawancara dengan pemilik showroom Nava Sukses Motor. Data sub kriteria dapat dilihat pada tabel berikut: 
Tabel 3. Data Sub Kriteria

\begin{tabular}{|c|c|c|}
\hline Kriteria & Sub Kriteria & $\begin{array}{c}\text { Bobot Sub } \\
\text { Kriteria }\end{array}$ \\
\hline \multirow{5}{*}{$\begin{array}{c}\text { Tahun } \\
\text { Pembuatan }\end{array}$} & 2016 & 1 \\
\hline & Dibawah 2000 & 2 \\
\hline & $2000-2005$ & 3 \\
\hline & $2006-2010$ & 4 \\
\hline & 2011-2015 & 5 \\
\hline \multirow{5}{*}{$\begin{array}{l}\text { Kapasitas } \\
\text { Mesin }\end{array}$} & $1200 \mathrm{cc}$ & 1 \\
\hline & $1500 \mathrm{cc}$ & 2 \\
\hline & $1800 \mathrm{cc}$ & 3 \\
\hline & $2000 \mathrm{cc}$ & 4 \\
\hline & Diatas $2000 \mathrm{cc}$ & 5 \\
\hline \multirow{5}{*}{$\begin{array}{l}\text { Warna } \\
\text { Mobil }\end{array}$} & Lainnnya & 1 \\
\hline & Abu-abu & 2 \\
\hline & Silver & 3 \\
\hline & Putih & 4 \\
\hline & Hitam & 5 \\
\hline \multirow{5}{*}{$\begin{array}{l}\text { Kisaran } \\
\text { Harga }\end{array}$} & Diatas 401 juta & 1 \\
\hline & $\begin{array}{c}301 \text { juta }-400 \\
\text { juta }\end{array}$ & 2 \\
\hline & $\begin{array}{c}201 \text { juta }-300 \\
\text { juta }\end{array}$ & 3 \\
\hline & $\begin{array}{c}101 \text { juta }-200 \\
\text { juta }\end{array}$ & 4 \\
\hline & 50 juta -100 juta & 5 \\
\hline
\end{tabular}

(Hasil analisis, 2016. Sumber: Showroom Nava Sukses Motor)

\section{Simulasi Perhitungan Pemilihan Mobil Bekas dengan Metode AHP dan SAW}

Proses perhitungan AHP dilakukan untuk mendapatkan nilai bobot prioritas dari kriteria-kriteria yang ada pada penyeleksian pemilihan mobil bekas, dalam hal ini yang akan diuraikan adalah Berikut ini merupakan langkah-langkah yang dilakukan dalam melakukan proses perhitungan AHP.

1) Menghitung bobot kriteria penyeleksian penerima beasiswa, dengan cara sebagai berikut:

a. Elemen $a[i, j]=1$, dimulai $i=1,2,3, \ldots$. Untuk penelitian ini $\mathrm{n}=5$.

b. Elemen matriks segitiga atas sebagai input. Pada tahap ini dilakukan penilaian perbandingan antara satu kriteria dengan kriteria yang lain. Hasil penilaian yang diperoleh dari kuisioner AHP dapat dilihat pada tabel berikut:

Tabel 4. Perbandingan berpasangan

Kriteria Pemilihan Mobil Bekas

\begin{tabular}{|c|c|c|c|c|}
\hline Kriteria & $\begin{array}{c}\text { Tahun } \\
\text { Pembuatan }\end{array}$ & $\begin{array}{c}\text { Kapasitas } \\
\text { Mesin }\end{array}$ & $\begin{array}{c}\text { Warna } \\
\text { Mobil }\end{array}$ & Harga \\
\hline $\begin{array}{c}\text { Tahun } \\
\text { Pembuatan }\end{array}$ & $1 / 1$ & $3 / 1$ & $5 / 1$ & $5 / 1$ \\
\hline $\begin{array}{c}\text { Kapasitas } \\
\text { Mesin }\end{array}$ & $1 / 3$ & $1 / 1$ & $2 / 1$ & $2 / 1$ \\
\hline $\begin{array}{c}\text { Warna } \\
\text { Mobil }\end{array}$ & $1 / 5$ & $1 / 2$ & $1 / 1$ & $2 / 1$ \\
\hline Harga Beli & $1 / 5$ & $1 / 2$ & $1 / 2$ & $1 / 1$ \\
\hline
\end{tabular}

Perbandingan Bobot Faktor Terhadap Goal Penentuan Pemilihan Mobil Bekas

1) Tahun pembuatan $3 x$ lebih penting dari kapasitas mesin

2) Tahun pembuatan $5 x$ lebih penting dari warna mobil

3) Tahun pembuatan $5 x$ lebih penting dari harga

4) Kapasitas mesin $2 x$ lebih penting dari warna mobil

5) Kapasitas mesin $2 x$ lebih penting dari harga

6) Warna mobil $2 x$ lebih penting dari harga 
Tabel 5. Matriks Bilangan Desimal Kriteria Pemilihan Mobil Bekas

\begin{tabular}{|c|c|c|c|c|c|c|}
\hline & $\begin{array}{c}\text { Tahun } \\
\text { Pembuat } \\
\text { an }\end{array}$ & $\begin{array}{c}\text { Kapasit } \\
\text { as } \\
\text { Mesin }\end{array}$ & $\begin{array}{c}\text { Warn } \\
\text { a } \\
\text { Mobi } \\
\text { I }\end{array}$ & $\begin{array}{c}\text { Harg } \\
\mathbf{a}\end{array}$ & $\begin{array}{c}\text { Vekt } \\
\text { or } \\
\text { Bobo } \\
\text { t }\end{array}$ & $\begin{array}{c}\text { Has } \\
\text { il }\end{array}$ \\
\hline $\begin{array}{c}\text { Tahun } \\
\text { Pembuat } \\
\text { an }\end{array}$ & 1 & 0,33 & 0,2 & 0,2 & 0,07 & 0,0 \\
\hline $\begin{array}{c}\text { Kapasitas } \\
\text { Mesin }\end{array}$ & 3 & 1 & 0,5 & 0,5 & 0,19 & 0,1 \\
\hline $\begin{array}{c}\text { Warna } \\
\text { Mobil }\end{array}$ & 5 & 2 & 1 & 0,5 & 0,31 & 0,3 \\
\hline Harga \\
Beli
\end{tabular}

(Sumber: Data Pribadi)

Tabel 6. Matriks Penjumlahan Kolom Kriteria Pemilihan Mobil Bekas

\begin{tabular}{|c|c|c|c|c|}
\hline Kriteria & $\begin{array}{c}\text { Tahun } \\
\text { Pembuatan }\end{array}$ & $\begin{array}{c}\text { Kapasitas } \\
\text { Mesin }\end{array}$ & $\begin{array}{c}\text { Warna } \\
\text { Mobil }\end{array}$ & Harga \\
\hline $\begin{array}{c}\text { Tahun } \\
\text { Pembuatan }\end{array}$ & 1,00 & 3,00 & 5,00 & 5,00 \\
\hline $\begin{array}{c}\text { Kapasitas } \\
\text { Mesin }\end{array}$ & 0,33 & 1,00 & 2,00 & 2,00 \\
\hline $\begin{array}{c}\text { Warna } \\
\text { Mobil }\end{array}$ & 0,20 & 0,50 & 1,00 & 2,00 \\
\hline Harga Beli & 0,20 & 0,50 & 0,50 & 1,00 \\
\hline
\end{tabular}

(Sumber: Data Pribadi)
Tabel 7. Matriks Penjumlahan Kolom Kriteria Pemilihan Mobil Bekas

\begin{tabular}{|c|c|c|c|c|}
\hline Kriteria & $\begin{array}{c}\text { Tahun } \\
\text { Pembuatan }\end{array}$ & $\begin{array}{c}\text { Kapasitas } \\
\text { Mesin }\end{array}$ & $\begin{array}{c}\text { Warna } \\
\text { Mobil }\end{array}$ & Harga \\
\hline $\begin{array}{c}\text { Tahun } \\
\text { Pembuatan }\end{array}$ & 0,07 & 0,06 & 0,05 & 0,09 \\
\hline $\begin{array}{c}\text { Kapasitas } \\
\text { Mesin }\end{array}$ & 0,2142 & 0,1875 & 0,1351 & 0,2272 \\
\hline $\begin{array}{c}\text { Warna } \\
\text { Mobil }\end{array}$ & 0,3571 & 0,375 & 0,2702 & 0,2272 \\
\hline Harga Beli & 0,3571 & 0,375 & 0,5405 & 0,4545 \\
\hline
\end{tabular}

Consistency Ratio merupakan parameter yang digunakan untuk memeriksa perbandingan berpasangan telah dilakukan dengan konsekuen atau tidak [6]. Penentuan parameter ini dalam kasus Pemilihan Mobil Bekas dilakukan dengan proses sebagai berikut :

1) Mengalikan nilai bilangan decimal dari setiap matrik kriteria dengan eigenvektor

Tabel 8. Matriks Kriteria Dengan Eigenvektor

\begin{tabular}{|c|c|c|c|c|c|c|}
\hline & $\begin{array}{c}\text { Tahun } \\
\text { Pembuat } \\
\text { an }\end{array}$ & $\begin{array}{c}\text { Kapasit } \\
\text { as } \\
\text { Mesin }\end{array}$ & $\begin{array}{c}\text { War } \\
\text { na } \\
\text { Mobi } \\
\mathbf{l}\end{array}$ & $\begin{array}{c}\text { Harg } \\
\mathbf{a}\end{array}$ & $\begin{array}{c}\text { Vekt } \\
\text { or } \\
\text { Bobo } \\
\mathbf{t}\end{array}$ & $\begin{array}{c}\text { Has } \\
\text { il }\end{array}$ \\
\hline $\begin{array}{c}\text { Tahun } \\
\text { Pembuat } \\
\text { an }\end{array}$ & 1 & 0,33 & 0,2 & 0,2 & 0,07 & 0,07 \\
\hline $\begin{array}{c}\text { Kapasita } \\
\text { s Mesin }\end{array}$ & 3 & 1 & 0,5 & 0,5 & 0,19 & 0,19 \\
\hline $\begin{array}{c}\text { Warna } \\
\text { Mobil }\end{array}$ & 5 & 2 & 1 & 0,5 & 0,31 & 0,31 \\
\hline $\begin{array}{c}\text { Harga } \\
\text { Beli }\end{array}$ & 5 & 2 & 2 & 1 & 0,43 & 0,43 \\
\hline
\end{tabular}

(Sumber: Data Pribadi)

2) Menghitung Consitency Vektor dengan jalan menentukan nilai rata-rata dari Weidhted Sum Vektor sebagai berikut :

$$
\begin{aligned}
0,28: & 0,07=4,0190 \\
0,77: & 0,19=4,0526 \\
1,26: & 0,31=4,0483 \\
1,78: & 0,43=4,1395
\end{aligned}
$$


3) Menghitung nilai rata-rata dari Consistency Vektor sebagai berikut :

$$
\Pi=\frac{(4,0190+4,0526+4,0483+4,1395)}{4}=4,0647
$$

4) Menghitung Nilai Consistency Index dengan menggunakan rumus

alternatif

$$
C I=\frac{(n-\mathrm{n})}{n-1} \mathrm{n}: \text { banyaknya }
$$

$$
\begin{aligned}
& C I=\frac{(4,0647-4)}{4-1} \\
& C I=0,0216
\end{aligned}
$$

5) Menghitung Consistency Ratio, dibutuhkan nilai RI yaitu Random Index yang didapat dari tabel Oarkridge $(\mathrm{CR}=\mathrm{CI} / \mathrm{RI})$.

Untuk $\mathrm{n}=4$, nilai RI adalah 0,90 . Jadi nilai CR untuk pemilihan mobil bekas adalah $0.0216 / 0,90=0.024$. Penilaian perbandingan dikatakan konsisten jika CR tidak lebih dari 0.10 , sehingga penilaian perbandingan kriteria pemilihan mobil bekas sudah konsisten dan tidak memerlukan revisi penilaian.

Tabel 9. Fungsi Kriteria Pemilihan Mobil Bekas

\begin{tabular}{|c|c|c|}
\hline No. & Kriteria & Fungsi \\
\hline 1 & Tahun Pembuatan & Benefit $(+)$ \\
\hline 2 & Kapasitas Mesin & Benefit $(+)$ \\
\hline 3 & Warna Mobil & Benefit $(+)$ \\
\hline 4 & Harga Beli & Cost $(-)$ \\
\hline
\end{tabular}

Tabel 10. Matrik Awal Nilai Alternatif Pemilihan Mobil Bekas

\begin{tabular}{|c|c|c|c|c|}
\hline \multirow{2}{*}{ Alternatif } & \multicolumn{4}{|c|}{ Kriteria Pemilihan Mobil Bekas } \\
\cline { 2 - 5 } & $\begin{array}{c}\text { Tahun } \\
\text { Pembuatan }\end{array}$ & $\begin{array}{c}\text { Kapasitas } \\
\text { Mesin }\end{array}$ & $\begin{array}{c}\text { Warna } \\
\text { Mobil }\end{array}$ & Harga \\
\hline Mobil 1 & 0,3 & 0,23 & 0,2 & 0,03 \\
\hline Mobil 2 & 0,3 & 0,23 & 0,1 & 0,1 \\
\hline Mobil 3 & 0,3 & 0,23 & 0,07 & 0,03 \\
\hline Mobil 4 & 0,4 & 0,23 & 0,1 & 0,05 \\
\hline Mobil 5 & 0,3 & 0,3 & 0,07 & 0,05 \\
\hline Bobot & 0,57 & 0,21 & 0,13 & 0,09 \\
\hline
\end{tabular}

\begin{tabular}{|c|c|c|c|c|c|c|}
\hline \multirow[b]{2}{*}{$\begin{array}{l}\text { Altern } \\
\text { atif }\end{array}$} & \multicolumn{4}{|c|}{ Kriteria Pemilihan Mobil Bekas } & \multirow[b]{2}{*}{$\begin{array}{l}\text { Tot } \\
\text { al }\end{array}$} & \multirow[b]{2}{*}{$\begin{array}{c}\text { Rank } \\
\text { ng }\end{array}$} \\
\hline & $\begin{array}{c}\text { Tahun } \\
\text { Pembua } \\
\text { tan }\end{array}$ & $\begin{array}{c}\text { Kapasi } \\
\text { tas } \\
\text { Mesin }\end{array}$ & $\begin{array}{c}\text { War } \\
\text { na } \\
\text { Mob } \\
\text { il }\end{array}$ & $\begin{array}{c}\text { Har } \\
\text { ga } \\
\text { Beli }\end{array}$ & & \\
\hline $\begin{array}{c}\text { Mobil } \\
1\end{array}$ & 4,29 & 1,21 & 0,65 & 0,07 & $\begin{array}{c}0,7 \\
6\end{array}$ & 2 \\
\hline $\begin{array}{c}\text { Mobil } \\
2\end{array}$ & 4,29 & 1,21 & 0,32 & 0,23 & $\begin{array}{c}0,7 \\
3\end{array}$ & 3 \\
\hline $\begin{array}{c}\text { Mobil } \\
\mathbf{3}\end{array}$ & 4,29 & 1,21 & 0,23 & 0,07 & $\begin{array}{c}0,6 \\
3\end{array}$ & 5 \\
\hline $\begin{array}{c}\text { Mobil } \\
4 \\
\end{array}$ & 5,71 & 1,21 & 0,32 & 0,12 & $\begin{array}{c}0,7 \\
8 \\
\end{array}$ & 1 \\
\hline $\begin{array}{c}\text { Mobil } \\
5\end{array}$ & 4,29 & 1,58 & 0,23 & 0,12 & $\begin{array}{c}0,7 \\
2\end{array}$ & 4 \\
\hline Bobot & 0,07 & 0,19 & 0,31 & 0,43 & & \\
\hline
\end{tabular}

(Sumber: Data Pribadi)
Tabel 11. Matrik Normalisasi Alternatif Pemilihan Mobil Bekas

(Sumber: Data Pribadi)

\section{Hasil Evaluasi Pemilihan Mobil Bekas dengan Metode Exact Match}

\section{Hasil Simulasi Data Awal vs Metode SAW}

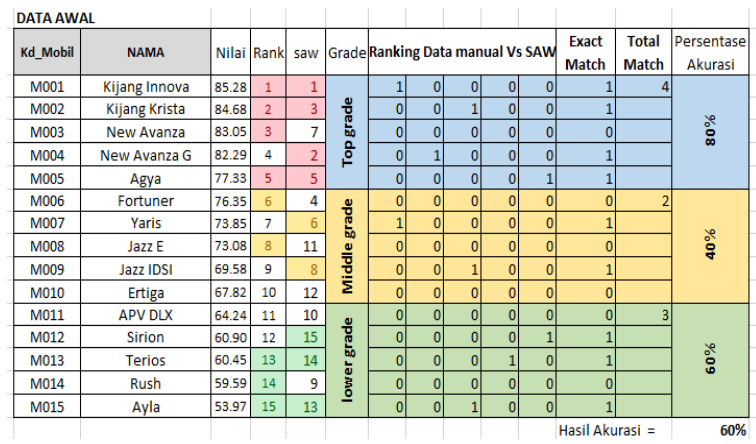

\section{Gambar 2. Simulasi Membandingkan Data Awal dengan Metode SAW}

Berdasarkan simulasi diatas untuk membandingkan Data Awal dengan Metode SAW terdapat hasil untuk Top Grade $80 \%$ dengan tingkat kecocokan 4 data, Middle Grade 40\% dengan tingkat kecocokan 2 data, dan Lower Grade $60 \%$ dengan tingkat kecocokan 3 data. Maka hasil akurasi yang diperoleh adalah $60 \%$. 


\section{Hasil Simulasi Data Awal vs Metode AHP dan SAW}

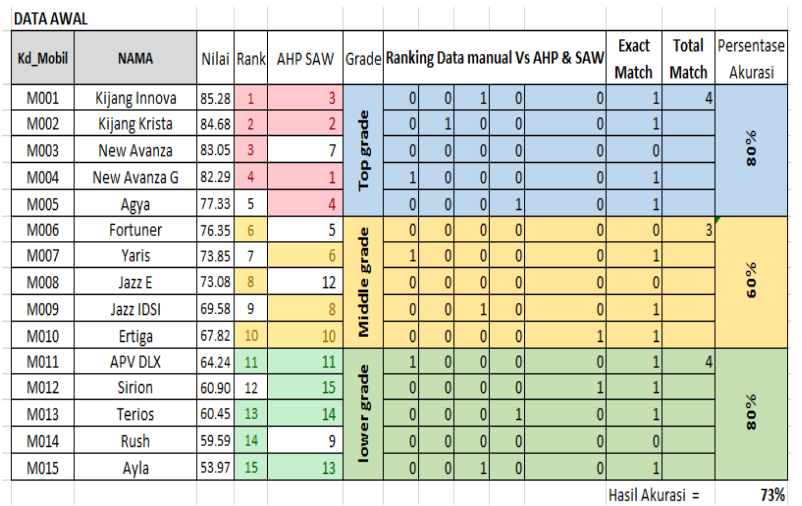

Gambar 3. Simulasi membandingkan Data Awal dengan Metode AHP dan SAW

Berdasarkan simulasi diatas untuk membandingkan Data Awal dengan Metode SAW terdapat hasil untuk Top Grade $80 \%$ dengan tingkat kecocokan 4 data, Middle Grade 60\% dengan tingkat kecocokan 4 data, dan Lower Grade $80 \%$ dengan tingkat kecocokan 4 data. Maka hasil akurasi yang diperoleh adalah $\mathbf{7 3 \%}$.

\section{Use Case Diagram}

Use case adalah rangkaian/uraian sekelompok yang saling terkait dan membentuk system secara teratur yang dilakukan atau diawasi oleh sebuah actor. Use case digunakan untuk membentuk tingkah laku benda / things dalam sebuah model serta di realisasikan oleh sebuah collaboration. Umumnya use case digambarkan dengan sebuah elips dengan garis yang solid, biasanya mengandung nama.

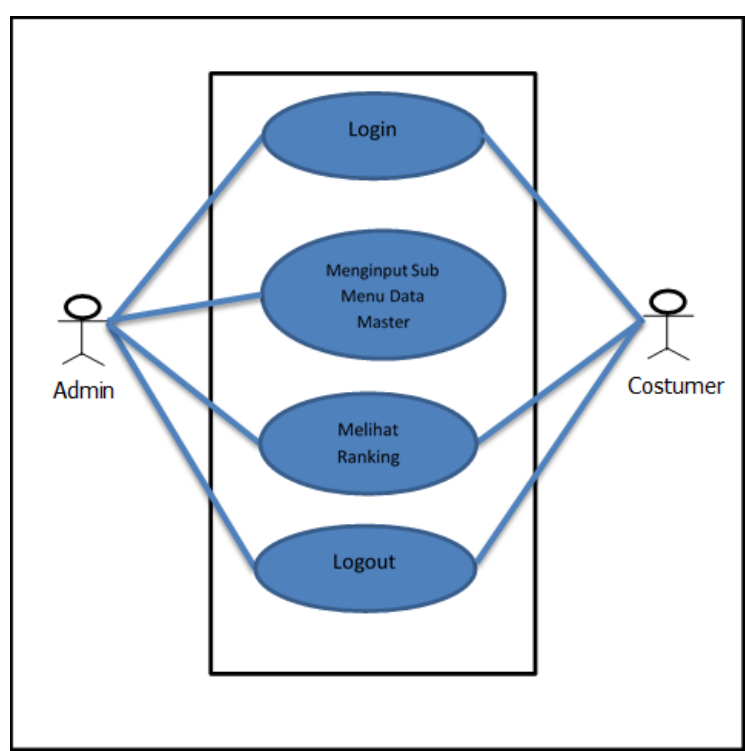

Gambar 4. Use Case Diagram

Tampilan Layar

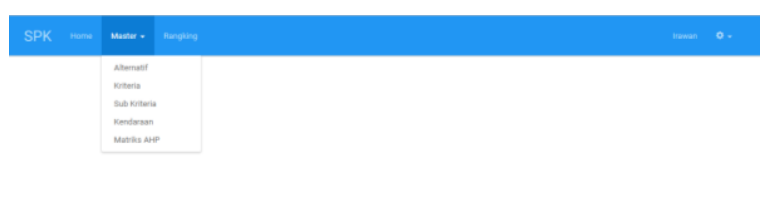

Gambar 5. Tampilan Menu Utama

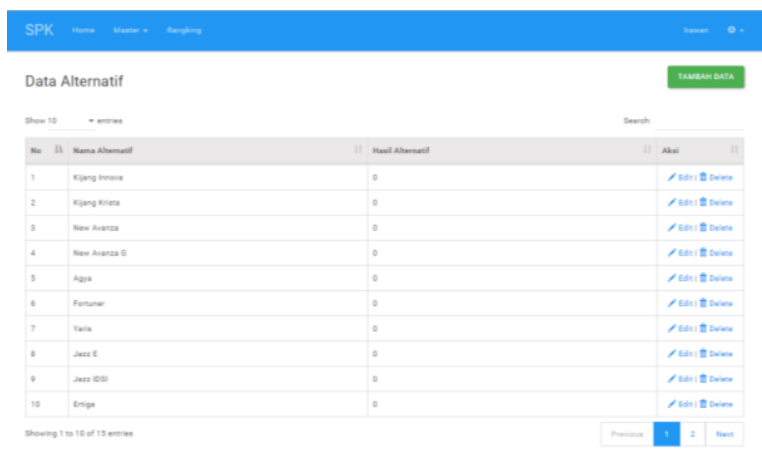

Gambar 6. Tampilan Layar Data Alternatif 


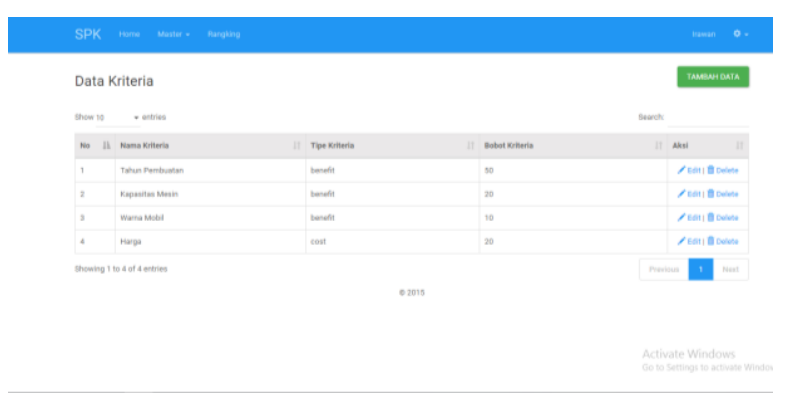

Gambar 7. Tampilan Data Kriteria

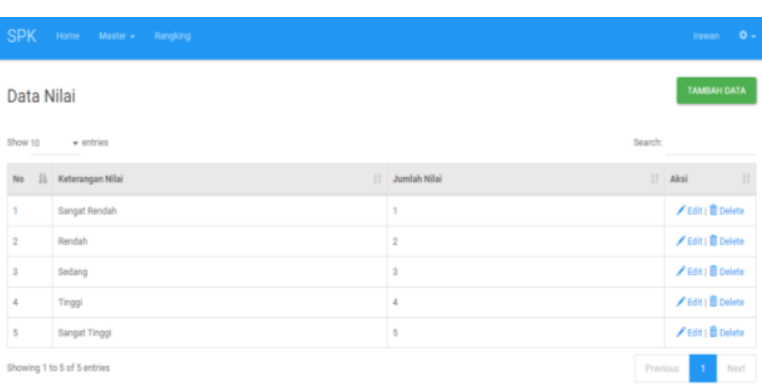

Gambar 8. Tampilan Layar Sub Data Kriteria

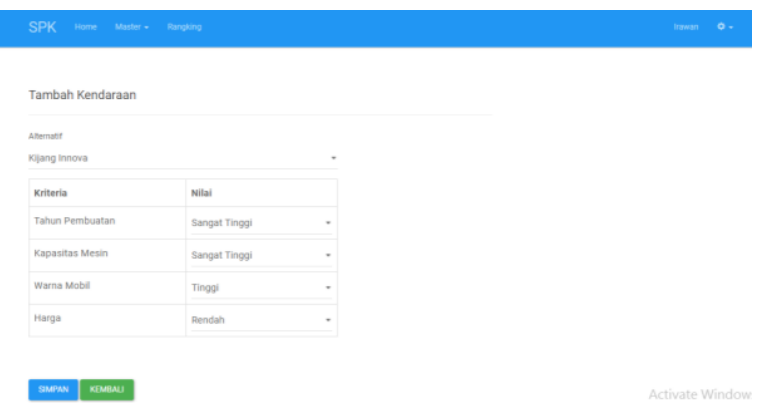

Gambar 9. Tampilan Data Kendaraan

\section{Pengujian Sistem}

Sistem yang telah dirancang perlu diuji untuk mengetahui tingkat efektifitas dan kehandalan sistem dalam menyelesaikan masalah yang ada. Selain sistem mudah digunakan, sistem juga harus dapat diterima oleh pihak-pihak yang akan menggunakan perancangan tersebut.

Menurut Pressman, setiap produk rekayasa perangkat lunak dapat diuji dalam salah satu kategori pengujian berikut [7] :

1) Pengujian Kotak Hitam (black-box testing), atau

2) Pengujian Kotak Putih (white-box testing). Dalam penelitian ini penulis menggunakan black-box testing yang dirancang untuk memvalidasi persyaratan fungsional tanpa perlu mengetahui kerja internal dari sebuah program. Teknik pengujian black-box testing berfokus pada ranah informasi dari perangkat lunak, menghasilkan test case dengan cara mempartisi ranah masukan (input) dan keluaran (output) dari sebuah program dengan cara mencakup pengujian yang menyeluruh.

Black-box testing juga merupakan sebuah metode yang digunakan untuk menemukan kesalahan dan mendemonstrasikan 
fungsionalitas aplikasi saat dioperasikan, apakah input diterima dengan benar dan output yang dihasilkan telah sesuai dengan yang diharapkan.

Responden yang terlibat dalam Black Box Testing sebanyak 5 (lima) orang yang terdiri dari 4 (empat) orang costumer showroom nava sukses motor dan 1 (satu) orang perwakilan dari staff showroom.

Tabel 12. Pengujian Kotak Hitam (Black Box Testing)

\begin{tabular}{|c|c|c|}
\hline Kelas Uji & Butir Uji & Jenis Pengujian \\
\hline Pengolahan \\
$\begin{array}{c}\text { Data Kriteria } \\
\text { Pemilihan Mobil } \\
\text { Bekas }\end{array}$ & $\begin{array}{c}\text { Tambah } \\
\text { Kriteria }\end{array}$ & Black Box \\
\cline { 2 - 3 } & $\begin{array}{c}\text { Ubah } \\
\text { Kriteria }\end{array}$ & Black Box \\
\cline { 2 - 3 } & $\begin{array}{c}\text { Hapus } \\
\text { Kriteria }\end{array}$ & Black Box \\
\hline \multirow{3}{*}{$\begin{array}{l}\text { Pengolahan } \\
\text { Data Mobil }\end{array}$} & $\begin{array}{c}\text { Tambah Data } \\
\text { Mobil }\end{array}$ & Black Box \\
\cline { 2 - 3 } & $\begin{array}{c}\text { Ubah Data } \\
\text { Mobil }\end{array}$ & Black Box \\
\cline { 2 - 3 } & $\begin{array}{c}\text { Hapus Data } \\
\text { Mobil }\end{array}$ & Black Box \\
\hline
\end{tabular}

\section{SIMPULAN}

Berdasarkan hasil uraian dan analisa yang telah dijabarkan, maka dari penelitian ini dapat ditarik kesimpulan sebagai berikut:

1. Sistem pendukung keputusan dengan metode AHP dan SAW dapat menyeleksi mobil bekas dengan cepat dan akurat sesuai dengan kriteria yang ditetapkan showroom nava sukses motor.

2. Hasil pengujian model system pendukung keputusan menggunakan Uji Konsisten Rasio (Consistency Ratio) terhadap pemilihan mobil bekas menghasilkan nilai $\mathrm{CR}$ sebesar 0,024 sehingga dapat dinyatakan bahwa penilaian kriteria sudah konsisten, karena kurang dari 0,10 .

3. Hasil pengujian software menggunakan metode black-box menghasilkan bahwa semua pengujian terhadap sistem berdasarkan persyaratan fungsional ini dapat diterima.

4. Hasil pengujian kualitas software berdasarkan 4 (empat) variable model McCall yaitu Functionality, Reliability, Usability, dan Efficiency. Hasil pengujian secara keseluruhan menunjukan secara kualitas aplikasi sistem pendukung keputusan pemilihan mobil bekas ini memiliki kriteria yang Baik yaitu 78,64\%.

\section{DAFTAR PUSTAKA}

[1] Kurniasih, D.L. Sistem Pendukung Keputusan Pemilihan Laptop Dengan Metode Topsis. Jurnal Pelita Informatika, Volume III Nomor 2. ISSN : 2301- 9425, STMIK Budi Darma Medan. 2013.

[2] Eniyati, Sri. Perancangan Sistem Pendukung Keputusan untuk Penerimaan Beasiswa Dengan Metode SAW (Simple Additive Weighting), Tugas Akhir Progam Studi Sistem Informasi Universitas Stikubank, Vol.16,No.2, hal.171-176. 2011.

[3] Aditya, Dodiet. Data dan Metode Pengumpulan Data Penelitian. Surakarta: Poltekkes Kemenkes Surakarta. 2013.

[4] Andrian dan Prasetya, R.A. Implementasi Metode Simple Additive Weighting Pada Sistem Pengambilan Keputusan Sertifikasi Guru. Jurnal Infomatika, Vol. 2, No. 2. 2011.

[5] F.Nugraha, B. Surarso, and B. Noranita. Sistem Pendukung Keputusan Evaluasi Pemilihan Pemenang Pengadaan Aset dengan Metode Simple Additive Weighting (SAW). JSINBIS (Jurnal Sistem Informasi Bisnis), Vol. 2, No. 2, pp. 067-072, Jun. 2012. 
[6] Marimin, M. Aplikasi Teknik Pengambilan Keputusan Dalam Manajemen Rantai Pasok. Bogor: IPB Press. 2010

[7] Agisa Rusaldi Wildan. White Box Testing \& Black Box Testing. 2013. 